\title{
CYSTATIN C AN EARLY MARKER OF GLOMERULAR DYSFUNCTION IN THALASSEMIA MAJOR.
}

1. M.Phil

Senior Lecturer Biochemistry

Avicenna Medical College Lahore, Pakistan.

2. M.Phil

Assistant Professor Biochemistry Islam medical and dental College Sialkot.

3. M.Phil

Assistant Professor Biochemistry, Avicenna Medical College Lahore, Pakistan.

4. M.Phil

Assistant Professor Biochemistry Avicenna Medical College, Lahore.

5. M.Phil

Assistant Professor Biochemistry Islam medical and dental College Sialkot.

6. M.Phil

Assistant Professor Biochemistry Services Institute of Medical

Sciences (SIMS) Lahore.

Correspondence Address:

Dr. Sumera Saghir

Senior Lecturer Biochemistry

Avicenna Medical College Lahore,

Pakistan.

sumerasaghir95@gmail.com

Article received on:

18/04/2019

Accepted for publication:

$15 / 07 / 2019$

\begin{abstract}
Sumera Saghir ${ }^{1}$, Adnan Riaz ${ }^{2}$, Aisha Hasan ${ }^{3}$, Yasir Ali Bhatti ${ }^{4}$, Ahmed Ashar Ghuman ${ }^{5}$,
\end{abstract} Muhammad Shakil ${ }^{6}$

ABSTRACT... Objectives: The objective of the present study is to investigate the role of cystatin $\mathrm{C}$ as an early marker of glomerular dysfunction in thalassemia major. Study Design: Cross sectional comparative study. Setting: Department of Biochemistry Post Graduate Medical institute and the Thalassemia Centre in Sir Ganga Ram Hospital Lahore. Period: July 2017 and July 2018. Material \& Methods: This study examined 90 male children all between the ages of 5-11, using non probability sampling techniques. The children were grouped as 21 healthy male children as control group I and 69 diagnosed male thalassemia major children further subdivided on the basis of serum ferritin level as group II, serum ferritin level <2500ng/ $\mathrm{ml}$, group III, serum ferritin level $2500-5000 \mathrm{ng} / \mathrm{ml}$ and group IV serum ferritin level $>5000 \mathrm{ng} /$ $\mathrm{ml}$ respectively. Individuals with hereditary renal diseases, on steroid therapy, or other comorbid renal diseases were excluded from the study. Complete blood analysis, serum ferritin, creatinine and cystatin $\mathrm{C}$ were measured by Micro lab 300 and solid phase enzyme linked immune sorbent assay (ELISA) respectively. The results were compared by using SPSS version 20. Results: Group I: $n=21$ healthy children with ferritin between normal range $105.33 \pm 30.03$, serum creatinine $0.41 \pm 0.05$, serum cystatin C $0.57 \pm 0.14$. eGFR-creatinine $133.38 \pm 7.63$, eGFR-cystatin C 122.9 \pm 17.63 . Group II: $\mathrm{n}=20$ ( $\beta$-TM with ferritin $<2500 \mathrm{ng} / \mathrm{ml}$ ). Mean ferritin was $1997.5 \pm 300.68 \mathrm{ng} / \mathrm{ml}(P<0.001)$, creatinine was $0.43 \pm 0.05$, serum cystatin $C 0.66 \pm$ $0.05(\mathrm{P}<0.05)$. eGFR-creatinine 121.45 $\pm 4.89 \mathrm{P}<0.05$, eGFR-cystatin $\mathrm{C} 105.15 \pm 6.49 \mathrm{P}<0.001$. Group III: $\mathrm{n}=25$ ( $\beta-\mathrm{TM}$ with ferritin $2500-5000 \mathrm{ng} / \mathrm{ml}$ ). Mean ferritin level was $3850.0 \pm 718.18$ $\mathrm{ng} / \mathrm{ml}(\mathrm{P}<0.001)$, creatinine was $0.5 \pm .07$, cystatin $\mathrm{C} 0.96 \pm 0.13(\mathrm{P}<0.001)$. eGFR-creatinine 103.29 $\pm 8.26(P<0.001)$, eGFR-cystatin $C 75.75 \pm 10.67(P<0.001)$. Group IV: $n=24(\beta-T M$ with ferritin $>5000 \mathrm{ng} / \mathrm{ml})$. Mean ferritin level was $6311.67 \pm 1060.61 \mathrm{ng} / \mathrm{ml} P$ value $(P<0.001)$, creatinine was $0.57 \pm 0.07$, cystatin $C 1.11 \pm 0.09(P<0.001)$. eGFR-creatinine $94.42 \pm 8.69$ $(P<0.001)$, eGFR cystatin $C 64.67 \pm 4.23(P<0.001)$. Conclusion: A highly significant positive relation was found between serum ferritin-cystatin $C$ as compared to creatinine among the study groups II, III and IV and significant inverse relationship between cystatin C and eGFR that concluded cystatin $\mathrm{C}$ as an early marker of glomerular dysfunction than creatinine in thalassaemia major children.

Key words: Cystatin C, EGFR, Transfusion Dependent Thalassemia Major Children Ferritin Creatinine.

Article Citation: Saghir S, Riaz A, Hasan A, Bhatti YA, Ghuman AA, Shakil M. Cystatin C an early marker of Glomerular dysfunction in thalassemia major. Professional Med J 2020; 27 (2):300-308. DOI: 10.29309/TPMJ/2020.27.2.3566

\section{INTRODUCTION}

Thalassemia's the heterogeneous inherited disorders of hemoglobin synthesis presenting with severe anemia early in life. The carrier population of thalassemia is up-to 150 million in more than 60 countries. ${ }^{1}$ The estimated carrier rate of thalassemia major ( $\beta$-TM) in Pakistan is about $5-7 \% .^{2}$ An imbalance in the globin chain synthesis and an excess of unmatched alpha (a) globin chain underlies the pathophysiology of anemia in $\beta$-TM children. Long standing anemia, iron overload cause epithelial and endothelial injury with progressive glomerular injury. ${ }^{3}$

$\beta$-TM children with severe anemia require longterm blood transfusion and chelation therapy to maintain $\mathrm{Hb}$ concentrations at around 9-10.5g/ dl. ${ }^{4}$

Chronic anemia, hypoxia, toxicity of iron chelators 
and iron overload due to repeated blood transfusion play an imperative role in developing complications in thalassaemic population. To avoid the deleterious effects of iron overload, iron chelation therapy is started at around $1000 \mathrm{ng} /$ $\mathrm{ml}$ of ferritin level, which is a standard practice in $\beta$-TM children and it usually occurs after $10^{\text {th }}$ to $12^{\text {th }}$ blood transfusions. Total body iron stores are routinely evaluated by serum ferritin estimation that has a therapeutic and prognostic role in the treatment of $\beta$-TM children estimation and is routinely done at interval of least 3 months. ${ }^{5}$

However, in transfusion- dependent thalassaemic children serum ferritin level below $2500 \mathrm{ng} / \mathrm{ml}$ is reported to have a better prognosis. ${ }^{6}$

Less is known about the effects of thalassemia on kidneys, however, anemia, chronic hypoxia, oxidative stress, iron excess and harmful effects of iron chelators can influence the normal functioning of the kidneys. ${ }^{7}$

Hyperdynamic circulation due to chronic anemia may increase renal plasma flow and glomerular filtration rate (GFR), however, longstanding anemia and hypoxia can also cause epithelial and endothelial injury with transudation of macromolecules into the mesangium thus contributing to progressive glomerular injury and decrease in GFR. ${ }^{3}$

GFR is measured by the plasma clearance of a substance in a unit of time by the kidney. Renal GFR an excellent guide to measure kidney function. Clearance of inulin and other exogenous techniques such as iohexol, ${ }^{51}$

Cr-EDTA, 99mTc-labeled diethylene triamine pentaacetic acid (DTPA) and ${ }^{25}$ labeled iothalamate are considered as the Gold standard exogenous techniques for GFR estimation. ${ }^{8}$

Therefore, in clinical settings use of endogenous marker for GFR estimation is routinely done. ${ }^{9}$ Estimation of GFR with serum and plasma creatinine is a widely used endogenous marker in routine clinical practice. ${ }^{10}$
Scr concentration also remains unchanged with a mild to moderate decrease in GFR. Subjects with moderate impairment of renal function present with unchanged Scr levels. ${ }^{11}$ Change in muscle mass, age, gender and race also influence creatinine level. ${ }^{12}$

Clinically cystatin-C (cys-C) cysteine proteinase inhibitor due its small size, continuous production by all cells in the body, free filtration at the glomeruli and metabolism in the proximal tubule, not affected by age, sex, gender and change in muscle mass is thought to be close to an ideal and sensitive endogenous indicator to estimate GFR as compared to creatinine in high risk patients. ${ }^{13}$ Cys- $C$ has an advantage of being an early and accurate indicator of glomerular dysfunction than creatinine in the pediatric population. ${ }^{14}$ Early detection of glomerular dysfunction with cys- $C$ can decrease the rate of renal failure and mortality. ${ }^{15}$ It was reported in a study conducted in 2014 that serum cys-C can detect stage II chronic kidney disease earlier than creatinine. ${ }^{16}$ In children with normal and reduced GFR, cys-C is more precise than creatinine to estimate GFR. ${ }^{9}$ Cys- $C$ has a positive correlation with Serum creatinine and negative relationship with GFR in thalassaemic population. ${ }^{17}$

Estimation of GFR in relation to serum ferritin levels using new endogenous marker cys- $\mathrm{C}$ may also help to delay the occurrence of the renal failure. ${ }^{6}$

The study was performed to ascertain whether there was glomerular damage due to anemia and iron overload in thalassemia major population and to investigate the potential utility of cystatin- $C$ as an early marker of glomerular dysfunction in thalassemia major children.

\section{MATERIALS AND METHODS}

This Cross sectional Comparative study was held between July 2017 and July 2018 after approval by the Ethical Review committee, Advanced Studies and Research Board of University of Health Sciences Lahore (attached as anexure I) at Post Graduate Medical Institute Lahore with Thalassemia Center in Sir Ganga Ram Hospital 
Lahore.

An informed verbal and written consent from the care takers of the patients was taken and their demographic data was recorded on a proforma. The inclusion criteria for the study was male children all between the ages of 5-11 of age. Children with the history hereditary renal diseases, recurrent urinary tract infections, valvular heart disease, liver diseases, and diabetes mellitus on steroids therapy and nephrotoxic drugs were excluded from the study. The study population was divided as group I control with 21 healthy male children and 69 thlassaemic children on regular blood transfusion with history of at least 10-12 blood transfusion/year, further subdivided as group II, III and IV on the basis of varying ferritin level.

Group 2: $n=20 \beta$-TM male children with ferritin $<2500 \mathrm{ng} / \mathrm{ml}$.

Group 3: $n=25 \quad \beta$-TM male children with ferritin 2500-5000ng/ml.

Group 4: $n=24 \quad \beta$-TM male children with ferritin $>5000 \mathrm{ng} / \mathrm{ml}$.

The sample size was calculated, with $80 \%$ power of study and $5 \%$ level of significance

Purposive blood sample was taken and $5 \mathrm{ml}$ of blood was collected from the median cubital vein by aseptic technique then poured in two vacutainers, $2 \mathrm{ml}$ in a vacutainer with ETDA for complete blood analysis and the test were carried out at the clinical pathological laboratory of Sir Ganga Ram Hospital Lahore. Remaining $3 \mathrm{ml}$ blood was taken in vacutainer without anticoagulant the test samples were allowed to clot at room temperature for 30 minutes centrifuged for 5 minutes at $4000 \mathrm{rpm}$ at PGMI Biochemical laboratory Lahore.

The serum was removed, aliquoted and stored at $-20^{\circ} \mathrm{C}$ at the Mid-City Pathological laboratory Hospital Lahore until assayed. The separated serum was used for the assays of cystatin- $C$ by Human cystatin C ELISA kit (Glory science Co. Ltd) for research only, quantitative serum ferritin estimation by Human Ferritin Enzyme Immune
Assay Test Kit Bio Check, INC. Catalog Number, BC-1025 and serum creatinine by creatinie liquid color Jaffe-Reaction, semi- automatic analyzer 5010.

\section{Statistical Analysis}

Statistical Analysis of the data was carried out using SPSS $\mathbf{2 0 . 0}$ for windows. Data were shown as the mean and standard deviation (SD). Independent student t-test was used for the comparison of two quantitative variables pair wise.

One way ANOVA was used for the comparison between the variables among the study groups. Findings were elaborated using, tables and graphs. $\mathrm{P}$ values $<0.05$ was considered statistically significant.

\section{RESULTS}

A total of 90 subjects were included in the study consisting of 21 controls in group I and 69 thalassemia major on regular blood transfusion in group II, III and IV. The mean serum ferritin levels were $105.33 \pm 30.03$ in the control and $1997.5 \pm 300.68 \mathrm{ng} / \mathrm{ml}, 3850.0 \pm 718.18 \mathrm{ng} / \mathrm{ml}$ and $6311.67 \pm 1060.61 \mathrm{ng} / \mathrm{ml}$ among the thalassaemic groups respectively (see Table-I,II).

eGFR calculations were carried out using Schwartz pediatric equation using creatinine and cystatin $\mathrm{C}$ among the control and group II,III and IV with varying Ferritin level.

The results concluded significant decrease in eGFR with $P<0.001$ among the thalassaemic groups II,III and IV with high ferritin levels as compared to creatinine which showed decrease eGFR in group IV as compared to group II and III but eGFR value remained within normal limits thus concluding cystatin $\mathrm{C}$ as an accurate and early marker of glomerular dysfunction. (Table-III)

There was significant difference in values of serum ferritin among the control and study groups on regular blood transfusion with or without iron chelation therapy. The frequency and number of blood transfusion per month was high in group III and IV as compared to group II, Table-IV \& V.

The mean serum creatinine level was $0.41 \pm$ 
$0.05 \mathrm{mg} / \mathrm{ml}$ and in the control and $0.43 \pm 0.05 \mathrm{mg} /$ $\mathrm{ml}, 0.5 \pm .07 \mathrm{mg} / \mathrm{ml} 0.57+0.07 \mathrm{mg} / \mathrm{ml}$ in the study groups II, III and IV respectively (Table-I\&II).

Serum cystatin $C 0.57 \pm 0.14 \mathrm{mg} / \mathrm{l}$ in the control group, and $0.66 \pm 0.05$ ( $\mathrm{P}<0.05), 0.96 \pm 0.13 \mathrm{mg} / \mathrm{l}$ $(P<0.001), 1.11 \pm 0.09 \mathrm{mg} / \mathrm{l}(\mathrm{P}<0.001)$ in the group II, III and IV children respectively (TableI\&II).
Results: Serum ferritin was significantly high with $(\mathrm{P}<0.001)$ in group II than the control group. Value of serum cysttin- $C$ was higher $(P<0.05)$ in group II than the control group.

Results: Level of serum ferritin was significantly high $P$ value $(P<0.001)$ in group IV than in group III. Group IV had high mean value $P$ value $(P<0.001)$ of serum cys- $C$ and serum creatinine than group III.

\begin{tabular}{|l|c|c|}
\hline \multicolumn{1}{|c|}{ Variables } & Group I (control) (21) & Group II.(20) \\
\hline Serum ferritin $\mathrm{ng} / \mathrm{ml}$ & $105.33+30.33$ & $1997.5+300.68$ \\
\hline Serum creatinine $\mathrm{mg} / \mathrm{dl}$ & $0.41+0.05$ & $0.43+0.05$ \\
\hline Serum Cystatin C & $0.57+0.14$ & $0.66+0.05$ \\
\hline
\end{tabular}

Table-I. Biochemical parameters Serum ferritin, creatinine and cystatin C group I (Control) and group II.

\begin{tabular}{|l|c|c|}
\hline \multicolumn{1}{|c|}{ Variables } & Group III (25) & Group IV(24) \\
\hline Serum ferritin $\mathrm{ng} / \mathrm{ml}$ & $3850 \pm 718.18$ & $6311.67 \pm 1060.61$ \\
\hline Serum creatinine $\mathrm{mg} / \mathrm{dl}$ & $0.5 \pm .07$ & $0.57 \pm 0.07$ \\
\hline Serum cystatin C & $0.96 \pm 0.13$ & $1.11 \pm 0.09$ \\
\hline
\end{tabular}

Table-II. Biochemical parameters serum ferritin, creatinine and cystatin C group III and group IV.

\begin{tabular}{|c|c|c|c|c|}
\hline Variables & Control groupl & Group II & Group III & Group IV \\
\hline eGFR creatinine $1.73 \mathrm{ml} / \mathrm{min}$ & $133.38 \pm 7.63$ & $\begin{array}{c}121.45 \pm 4.89 \\
P<0.05\end{array}$ & $103.29 \pm 8.26(P<0.001)$ & $94.42 \pm 8.69(\mathrm{P}<0.001)$ \\
\hline eGFR cystatin $\mathrm{C} 1.73 \mathrm{ml} / \mathrm{min}$ & $122.9 \pm 17.63$ & $\begin{array}{c}105.15 \pm 6.49 \\
P<0.001\end{array}$ & $\begin{array}{c}\text { eGFR-cystatin C } \\
75.75 \pm 10.67(P<0.001) .\end{array}$ & $\begin{array}{c}\text { GFR cystatin C } \\
64.67 \pm 4.23(P<0.001)\end{array}$ \\
\hline
\end{tabular}

\begin{tabular}{|l|c|c|c|}
\hline Group II $\mathbf{n =}(\mathbf{2 0})$ & $\begin{array}{c}\text { Number of Blood } \\
\text { transfusion/ month }\end{array}$ & $\begin{array}{c}\text { Frequency of transfusion/ } \\
\text { month }\end{array}$ & $\begin{array}{c}\text { Percentage of blood } \\
\text { transfusion }\end{array}$ \\
\hline & 1 & 4 & $20 \%$ \\
\hline & 2 & 12 & $60 \%$ \\
\hline Group III $\mathbf{n = 2 5}$ & 3 & 3 & $15 \%$ \\
\hline & 4 & 1 & $5 \%$ \\
\hline & 1 & 4 & $16 \%$ \\
\hline & 2 & 12 & $48 \%$ \\
\hline & 3 & 8 & $32 \%$ \\
\hline & 4 & 1 & $4 \%$ \\
\hline & 1 & & $20 \%$ \\
\hline & 2 & 5 & $29 \%$ \\
\hline & 3 & 7 & $25 \%$ \\
\hline
\end{tabular}

Table-IV. Frequency and percentage of blood transfusion per month in group II, III and IV. 


\begin{tabular}{|l|c|c|c|c|c|}
\hline \multicolumn{1}{|c|}{ Group II $\mathbf{n = 2 0}$} & Group III & & Group IV & \\
\hline $\begin{array}{l}\text { Type of Iron } \\
\text { chelation }\end{array}$ & $\begin{array}{c}\text { Percentage of iron } \\
\text { chelation therapy }\end{array}$ & $\begin{array}{c}\text { Type of Iron } \\
\text { chelation }\end{array}$ & $\begin{array}{c}\text { Percentage of iron } \\
\text { chelation therapy }\end{array}$ & $\begin{array}{c}\text { Type of Iron } \\
\text { chelation }\end{array}$ & $\begin{array}{c}\text { Percentage of iron } \\
\text { chelation therapy }\end{array}$ \\
\hline Oral & $20 \%$ & Oral & 5 & Oral & $4 \%$ \\
\hline Cap hydrea & $20 \%$ & Cap hydrea & 2 & Cap hydrea & $8 \%$ \\
\hline Irregular & $35 \%$ & Irregular & 8 & Irregular & $16 \%$ \\
\hline No chelation & $20 \%$ & No chelation & 5 & No chelation & $25 \%$ \\
\hline $\begin{array}{l}\text { Intravenous } \\
\text { chelation }\end{array}$ & $5 \%$ & $\begin{array}{c}\text { Intravenous } \\
\text { chelation }\end{array}$ & 5 & $\begin{array}{c}\text { Intravenous } \\
\text { chelation }\end{array}$ & $8 \%$ \\
\hline
\end{tabular}

Table-V. Frequency and percentage of Iron chelation therapy in group II, III and IV.

\section{DISCUSSION}

Blood transfusion is important for the normal growth and development in thalassemia major patients. Repeated blood transfusions can inevitably lead to iron overload which could cause organ damage thus increasing the mortality. During the last decade, a large number of studies and available literature revealed an interest in cys- $\mathrm{C}$ a new endogenous marker of glomerular dysfunction. Previously some studies and recent study by Hamad and El Meglegy in 2010 also stated that the early detection of renal dysfunction with these specific early markers may interrupt the progression of renal damage in thalassaemic population. ${ }^{18}$

In past $\beta$-TM children did not live long to develop conditions linked to kidney dysfunction. However, the advent of iron chelation therapy increased the life expectancy of $\beta$-TM children and had allowed previously unnoticed renal complications to emerge..$^{19}$

Qari and his co-workers in 2013 reported that in thalassemia major children, complications of iron overload resulting in excess of free iron with the production of injurious hydroxyl radicals thus increasing the complexity of the disease. A study by reported progressive renal failure to be one the main complications in $\beta$ TM children. ${ }^{20,21}$

Mishra and Tiwari in 2013 documented about $5 \mathrm{gm}$ of hepatic iron deposition within 1 year of regular blood transfusions in a child who gets 25 units of blood transfusion per year without any iron chelation therapy. Markedly high serum ferritin level of $1997.5 \pm 300.68,3850.0 \pm 718.18$ $\mathrm{ng} / \mathrm{ml}$ and $6311.67 \pm 1060.6 \mathrm{ng} / \mathrm{ml}$ was found among the study groups II, III and IV, the results were similar to recent work by Riaz et al., in 2011, which reported mean ferritin levels of $4236.5 \mathrm{ng} /$ $\mathrm{ml}$ in transfusion dependent thalassemia major children. ${ }^{22,23}$

The use of iron chelation also affect functioning of glomeruli as DFO (Deferoxamine) given intravenously can also cause renal toxicity when given in high dose. However, DFO has decreased the rate of mortality by decreasing the cardiac and other complications. ${ }^{24}$ The same year in 2015 Ricchi and Marsella also stated the use of oral iron chelator DFP where iron chelation with DFO is not appropriate for treating iron overload. ${ }^{25}$

Financial constraints observed in this study, with monthly low family income around 1400016000 rupees/ month also contributed to the non-compliance of the treatment/chelation therapy among the thalassaemic study groups. The results observed in the study were similar to work published by Arif and his co-workers in 2008, which documented an alarming impact of socioeconomic conditions and distressing psychological burden on the families of thalassaemic children. ${ }^{26}$ According to a study by Cunningham in 2004, lifelong transfusion and chelation treatment is a challenging task especially in developing countries where the prevalence of disease and related to health problems is high. ${ }^{27}$

It was observed in the present study that blood transfusions were repeated irregularly (3 or 3-4 times/month) with an interval of less than 1-2 weeks in children with ferritin level between 2000 $\mathrm{ng} / \mathrm{ml}$ to $>5000 \mathrm{ng} / \mathrm{ml}$. It was also found that almost all the patients were under transfused 
with hemoglobin level below $10 \mathrm{gm} / \mathrm{dl}$. Increase in frequency of blood transfusion and iron mediated toxicity greater than $2500 \mathrm{ng} / \mathrm{ml}$ observed in the present study was similar to high mean serum ferritin level in thalassemia major children patients with and without chelation therapy, reported by Shah and his colleagues in $2010 . .^{28}$

A recent work by Filler and his co-team in 2012 stated, even though creatinine is commonly used in clinical practice to estimate GFR, yet it does not share the properties of an ideal marker of GFR estimation like inulin. Hence due to the certain limitation with the use of serum creatinine as a marker for GFR estimation, use of small molecular weight protein cys- $\mathrm{C}$, produced constantly by all nucleated cells in the body is in clinical trials as an early and potent marker to assess glomerular damage. ${ }^{29}$

A work published by Inker et al., 2012 also recognized the diagnostic inaccuracy of creatinine for GFR estimation due to variation in creatinine level with the change in muscle mass, age and gender and stated cys- $C$ as a substitute and better marker than creatinine for eGFR. ${ }^{30}$ Earlier work by Tanaka and his co-workers in 2007 also reported that serum cys- $C$ remains unaffected with a change in age, gender and muscle mass and is a better and superior marker than creatinine to predict GFR. ${ }^{31}$ Shilpak and his co-team in 2013 also discovered the significance of cys-C as a predictor of cardiovascular problems in diabetics and in metabolic syndromes. ${ }^{32}$

Results of the present study revealed 0.43 to 0.57 $\mathrm{mg} / \mathrm{dl}$ of serum creatinine level among the study groups, the level of serum creatinine was normal even with $50 \%$ reduction in GFR. Whereas, an increase in cys-C from 0.66 to $1.2 \mathrm{mg} / \mathrm{l}$ was observed in relation to high ferritin levels. A decrease in GFR was observed among the study groups with or without chelation therapy. The increase in serum cys- $C$ observed in this study also indicated an indirect correlation of cys- $C$ with GFR and a positive correlation of cys- $C$ with serum ferritin level. The results of this study were similar to work published by Westhuizen in 2006 which also reported cystatin $\mathrm{C}$ as a useful biomarker of renal dysfunction. These authors established that serum cys- $C$ was a sensitive marker for renal impairment defined as GFR $<80 \mathrm{ml} / \mathrm{min} / 1.73 \mathrm{~m}^{2}$

The present study signifies the usefulness of cys- $C$ in identifying reasonably impaired renal function in transfusion dependent $\beta$-TM children due to iron overload. Similar results were reported by Peiris and his co-workers in 2008 which documented the diagnostic cut-off value of $1.25 \mathrm{mg} / \mathrm{l}$ of cystatin $\mathrm{C}$ for the recognition of patients with moderately impaired renal function with a single random blood sample. ${ }^{11}$ Murty and his colleagues signifies the accuracy of cystatin $c$ in estimationg a decrease in GFR in creatinine blind range (between 40 and $70 \mathrm{ml} / \mathrm{min} / 1.73 \mathrm{~m}^{2}$ ).

Earlier a work by Safaie and co-workers in 2008 demonstrated a positive correlation between serum ferritin and predictors of tubular toxicity. Whereas, another study by Koliakos and his co-fellows in 2003 reported glomerular rather than tubular damage with a high level of serum ferritin in $\beta$-TM children. ${ }^{33}$ Recent work in 2017 by Behairy and his co-workers concluded that glomerular dysfunction in beta thalassemia is not an uncommon complication and cys- $\mathrm{C}$ may be a better marker that could predict earlier slight changes in glomerular filtration rate, as compared to creatinine.

The results of this study were similar to work done by Ali and Mahmoud in 2014, who found that serum cys- $C$, is superior for GFR estimation when compared to other estimates in thalassemia major children. An inverse relationship of cys-C and eGFR was found in the present study among the study groups with serum ferritin $>2000 \mathrm{ng} /$ $\mathrm{ml}$. Moreover, a significant decrease in eGFR from $105-64 \mathrm{ml} / \mathrm{min} / 1.72 \mathrm{~m}^{2}$ calculated with cy-C was also observed among the study groups with ferritin level from > $2500 \mathrm{ng} / \mathrm{ml}$ to $>5000 \mathrm{ng} / \mathrm{ml}$ and eGFR calculated with creatinine had values from $121-94 \mathrm{ml} / \mathrm{min} / 1.72 \mathrm{~m}^{2}$ respectively. ${ }^{16}$

\section{CONCLUSION}

Iron overload due to irregular iron chelation, low socioeconomic status, lack of education and insufficient health care facilities among the 
thalassemia major patients were the main factors which contributed to ineffective treatment.

In terms of pre-transfusion low $\mathrm{Hb}(7-9 \mathrm{gm} / \mathrm{dl})$ observed in our study was due to ineffective erythropoiesis. The frequency of blood transfusion increased with the increase in age from one transfusion/month to 3-4 per month.

The present data confirmed that glomerular dysfunctions exist in beta thalassemia major children. These abnormalities were mainly subclinical.

Highly significantly positive correlation of cys- C with serum ferritin level as compared to serum creatinine was found in thalassemia major children on regular blood transfusions.

The study concluded a rise in serum cystatin C level greater than normal when GFR was $71 \mathrm{ml} /$ $\mathrm{min} / \mathrm{m}^{2}$ on the other hand serum creatinine level increased within normal limits at GFR was $88 \mathrm{ml} / \mathrm{min} / \mathrm{m}^{2}$. This study thus concluded the significance of serum cystatin $\mathrm{C}$ in the estimation of mild reduction in GFR which was overlooked with creatinine.

The comparison between eGFR calculated with serum cystatin- $C$ and creatinine in thalassemia major children concluded a significant inverse correlation of cys- $C$ as compared to creatinine with eGFR in group II III and IV, the results and data of the present study thus concluded cystatin $\mathrm{C}$ as an early marker of glomerular dysfunction than creatinine in transfusion dependent thalassemia major children.

Early identification of renal dysfunction with cys-C for the high-risk thalassaemic population on regular blood transfusion may help to take specific measure to avoid renal complications. Therefore, the routine use of new marker cys- $C$ for early detection of glomerular dysfunction is recommended for all thalassemia major patients on regular blood transfusions, to diagnose and manage the subclinical renal involvement and its related complications, present study data might be a help for further research regarding glomerular complications due to iron overload in thalassemia major population.

\section{Copyright $(15$ July, 2019.}

\section{REFERENCES}

1. Cao A, Galanello R. Beta-thalassemia. Genetics in medicine. 2010 Feb; 12(2):61.

2. Ansari SH, Shamsi TS, Ashraf M, Bohray M, Farzana T, Khan MT, Perveen K, Erum S, Ansari I, Nadeem M, Ahmed M. Molecular epidemiology of $\beta$-thalassemia in Pakistan: Far reaching implications. International Journal of Molecular Epidemiology and Genetics. 2011; 2(4):403.

3. Marengo-Rowe AJ. The thalassemias and related disorders. In Baylor university medical center proceedings. 2007 Jan 1 (Vol. 20, No. 1, pp. 27-31). Taylor \& Francis.

4. Anwar I, Amanat S, Khalid A. Effectiveness of Iron Chelation Therapy Using Serum Ferritin Levels in Thalassemia Major Patients. International Journal of Pathology. 2018 Nov 22:20-4.

5. Ikram N, Hassan K, Younas M, Amanat S. Ferritin levels in patients of beta thalassaemia major. Int $\mathrm{J}$ Pathol. 2004; 2(2):71-4.

6. Faruqi A, Ahmed ST, Ahmed F, Association of Serum Ferritin Levels with Haematological Parameters in Thalassaemia Major Patients. Journal of Rawalpindi Medical College (JRMC); 2014; 18(2):219-221 219

7. Adly AA, Toaima DN, Mohamed NS, El Seoud KM. Subclinical renal abnormalities in young thalassemia major and intermedia patients and its relation to chelation therapy. Egyptian Journal of Medical Human Genetics. 2014; 15(4):369-77.

8. Jahan N, Ferdousi S. Cystatin C-a Promising Marker of Glomerular Filtration Rate. Bangladesh Journal of Medical Biochemistry. 2013 Jan 13; 6(1):26-30.

9. Sarkar PD, Rajeshwari G, Shivaprakash TM. Cystatin C-A novel marker of glomerular filtration rate: $A$ review. Indian Journal of Clinical Biochemistry. 2005 Jan $1 ; 20(1): 139-44$

10. Chew JS, Saleem M, Florkowski CM, George PM. Cystatin C-a paradigm of evidence based laboratory medicine. The Clinical Biochemist Reviews. 2008 May; 29(2):47.

11. Peiris, H., Chadrasena, LG.and Lanerolle, RD. Serum cystatin $\mathbf{C}$ as a marker to identify patients with moderately impaired renal function. Indian Journal of Clinical Biochemistry. 2008. 23(2): 163-166. 
12. Pottel H, Hoste L, Dubourg L, Ebert N, Schaeffner E, Eriksen BO, Melsom T, Lamb EJ, Rule AD, Turner ST, Glassock RJ. An estimated glomerular filtration rate equation for the full age spectrum. Nephrology Dialysis Transplantation. 2016 Feb 29; 31(5):798-806.

13. Beben T, Rifkin DE. GFR estimating equations and liver disease. Advances in chronic kidney disease. 2015 Sep 1; 22(5):337-42.

14. Finney $H$, Newman DJ, Thakkar H, Fell JM, Price CP. Reference ranges for plasma cystatin $\mathbf{C}$ and creatinine measurements in premature infants, neonates, and older children. Archives of disease in childhood. 2000 Jan 1; 82(1):71-5.

15. Tantawy AA, El Bablawy N, Adly AA, Ebeid FS. Early predictors of renal dysfunction in Egyptian patients with $\beta$-thalassemia major and intermedia. Mediterranean journal of hematology and infectious diseases. 2014; 6(1).

16. Ali BA, Mahmoud AM. Frequency of glomerular dysfunction in children with beta thalassaemia major. Sultan Qaboos University Medical Journal. 2014 Feb; 14(1):e88.

17. Papassotiriou I, Margeli A, Hantzi E, Delaporta P, Sergounioti A, Goussetis E, Ladis V, Kattamis A. Cystatin C levels in patients with $\beta$-thalassemia during deferasirox treatment. Blood Cells, Molecules, and Diseases. 2010 Mar 15; 44(3):152-5.

18. Hamed EA, EIMelegy NT. Renal functions in pediatric patients with beta-thalassemia major: Relation to chelation therapy: original prospective study. Italian journal of pediatrics. $2010 \mathrm{Dec} ; 36(1): 39$.

19. Bakr A, Al-Tonbary Y, Osman G, El-Ashry R. Renal complications of beta-thalassemia major in children. American journal of blood research. 2014; 4(1):1.

20. Qari $M H$, Wali $Y$, Albagshi $M H$, Alshahrani M, Alzahrani A, Alhijji IA, Almomen A, Aljefri A, Al Saeed HH, Abdullah $S$, Al Rustumani A. Regional consensus opinion for the management of beta thalassemia major in the Arabian Gulf area. Orphanet journal of rare diseases. 2013 Dec 1; 8(1):143.

21. Voskaridou E, Terpos E, Michail S, Hantzi E, Anagnostopoulos A, Margeli A, Simirloglou D, Loukopoulos D, Papassotiriou I. Early markers of renal dysfunction in patients with sickle cell/ $\beta$-thalassemia. Kidney international. 2006 Jun 1; 69(11):2037-42.

22. Mishra AK, Tiwari A. Iron overload in Beta thalassaemia major and intermedia patients. Maedica. 2013 Sep; 8(4):328.
23. Riaz, H.,Riaz,T.,Khan, M.U., Aziz,S., Ullah, F., Rehman,A., Zafar,Q. and Kazi, A.N. Serum ferritin levels, socio demographic factors and desferrioxamine therapy in multi transfused thalassemia major patients at a government tertiary care hospital of Karachi, Pakistan. BMC Research. B.M.C., Research Notes, $20114: 287$.

24. Saliba AN, Harb AR, Taher AT. Iron chelation therapy in transfusion-dependent thalassemia patients: current strategies and future directions. Journal of blood medicine. 2015; 6:197.

25. Ricchi P, Marsella M. Profile of deferasirox for the treatment of patients with non-transfusiondependent thalassemia syndromes. Drug design, development and therapy. 2015; 9:6475.

26. Arif F, Fayyaz J, Hamid A. Awareness among parents of children with thalassemia major. J Pak Med Assoc. 2008 Nov; 58(11):621-4.

27. Cunningham MJ, Macklin EA, Neufeld EJ, Cohen AR, Thalassemia clinical research network. Complications of $\beta$-thalassemia major in North America. Blood. 2004 Jul 1; 104(1):34-9.

28. Shah N, Mishra A, Chauhan D, Vora C, Shah NR. Study on effectiveness of transfusion program in thalassemia major patients receiving multiple blood transfusions at a transfusion centre in Western India. Asian journal of transfusion science. 2010 Jul; 4(2):94.

29. Filler G, Huang SH, Yasin A. The usefulness of cystatin $\mathrm{C}$ and related formulae in pediatrics. Clinical chemistry and laboratory medicine. 2012 Dec 1; 50(12):2081-91.

30. Inker LA, Schmid CH, Tighiouart H, Eckfeldt JH, Feldman HI, Greene T, Kusek JW, Manzi J, Van Lente F, Zhang $\mathrm{YL}$, Coresh J. Estimating glomerular filtration rate from serum creatinine and cystatin C. New England Journal of Medicine. 2012 Jul 5; 367(1):20-9.

31. Tanaka A, Suemaru K, Araki H. A new approach for evaluating renal function and its practical application. Journal of pharmacological sciences. 2007:0709070001-.

32. Peralta CA, Shlipak MG, Judd S, Cushman M, McClellan W, Zakai NA, Safford MM, Zhang X, Muntner $P$, Warnock D. Detection of chronic kidney disease with creatinine, cystatin $\mathrm{C}$, and urine albumin-tocreatinine ratio and association with progression to end-stage renal disease and mortality. Jama. 2011 Apr 20;305(15):1545-52. 
33. Koliakos G, Papachristou F, Koussi A, Perifanis V, Tsatra I, Souliou E, Athanasiou M. Urine biochemical markers of early renal dysfunction are associated with iron overload in $\boldsymbol{\beta}$-thalassaemia. Clinical \& Laboratory Haematology. 2003 Apr; 25(2):105-9.

\begin{tabular}{|c|c|c|c|}
\hline \multicolumn{4}{|c|}{ AUTHORSHIP AND CONTRIBUTION DECLARATION } \\
\hline Sr. \# & Author(s) Full Name & Contribution to the paper & Author(s) Signature \\
\hline 1 & Sumera Saghir & $\begin{array}{l}\text { Corresponding author, Research } \\
\text { plan, write up, experiment }\end{array}$ & 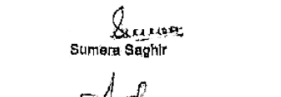 \\
\hline 2 & Adnan Riaz & $\begin{array}{l}\text { conduction. } \\
\text { Experimental work, write up, } \\
\text { Proof reading. }\end{array}$ & 4 \\
\hline 3 & Aisha Hasan & Experimental work,write up. & Alsha fiveszan \\
\hline 4 & Yasir Ali Bhatti & Research plan, proof reading. & renta \\
\hline 5 & Ahmed Ashar Ghuman & Experimental work. & 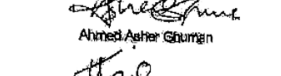 \\
\hline 6 & Muhammad Shakil & Proo reading. & edstration: \\
\hline
\end{tabular}

